\title{
Tourists, local food and the intention-behaviour gap
}

${\text { Dawn } \text { Birch }^{1} \text { and Juliet Memery }}^{2}$

${ }^{1}$ School of Business, University of the Sunshine Coast, Sippy Downs, Australia.

${ }^{2}$ The Business School, Bournemouth University, Bournemouth, UK.

Dr Dawn Birch, School of Business, Faculty of Arts, Business and Law, University of the Sunshine Coast, 90 Sippy Downs Drive, Sippy Downs, Queensland, Australia 4556.

Email: dbirch@usc.edu.au

Professor Juliet Memery, The Business School, Faculty of Management, Bournemouth

University, Executive Business Centre, 89 Holdenhurst Road, Bournemouth, UK. BH8 8EB.

Email: jmemery@bournemouth.ac.uk

\section{Acknowledgements:}

This work was supported by the Australian Queensland Government under Grant 0980021972. 


\begin{abstract}
Food tourism is a growing phenomenon with a particular emphasis on experiencing authentic and traditional local foods, which provides a vehicle for local producers and service providers to develop regional identities, enhance environmental awareness, and conserve traditional ways of life. However, past research indicates that whilst many tourists are interested in local food and drink, a number do not consume any whilst visiting a destination. This study explores why this intention behaviour gap may occur. Five hypotheses are tested using data collected from a sample of 546 respondents recruited via an online panel of visitors to South East Queensland, Australia. Regression analysis explores differences in attitudes, behaviours, barriers and drivers, and concludes an intention-behaviour (purchase) gap is evident. Whilst future visitors had high intentions to purchase local food, past visitors purchased less than might be anticipated. This is possibly due to past visitors holding less favourable attitudes and beliefs than future visitors due to expectations not being met. Key perceived barriers associated with lack of marketing and distribution, inconvenience, price and quality issues, and lack of trust the product is actually local may compound the issue. Practical suggestions are offered to producers, service providers and management on how they may close the intention/behaviour gap through a variety of marketing, distribution and communication strategies. This study provides new insight into why what visitors say they will do may not translate into actual behaviour, an area that has not been explored previously in this context, through studying the drivers/barriers to purchase/consumption.
\end{abstract}

Keywords: tourists, local food, attitudes, intention-behaviour gap, purchase barriers and drivers

Article Classification: Research Paper 


\section{Introduction}

Food is an important facet of everyday life and a topic that has received much attention in academic studies with regard to how and why people buy and consume what they do. Of growing interest is the role of food in tourism and the way it can affect the tourist experience. Food is considered integral to the travel experience (Bessiere, 1998; Björk \& KauppinenRäisänen, 2014; Correia, 2008; Henderson, 2009; Horng, Liu, Chou, \& Tsai, 2012) being viewed as an entertainment activity, a cultural attraction (Cohen \& Avieli, 2004; Mak, Lumbers, Eves, \& Chang, 2017; Sengel et al, 2015) and a key reason people visit a destination (Kim, Eves, \& Scarles, 2009). Indeed, the consumption of food and drink, particularly those products considered 'local' to a destination/area are viewed as part of the cultural character (Sengel et al, 2015) or image (Ab Karim, \& Chi, 2010; Seo, Yun, \& Kim, 2014) of a place and hence may be used as a competitive marketing tool for tourist destinations (Boniface, 2003; Kivela \& Crotts, 2006). Lee, Scott and Packer (2014) argue that while people with a high level of interest in food may not primarily base their travel destination decisions on the food of the region, they are likely to undertake food related activities once they have arrived. Furthermore increasing interest in food tourism has been linked to developing and sustaining regional identities, enhancing environmental awareness and sustainability, increasing social and cultural benefits, and preserving traditional ways of life (Everett \& Aitchison, 2008).

Past research indicates expenditure on eating out whilst on holiday accounts for a significant portion of the tourists budget (McKercher, Okumus, \& Okumus, 2008; Telfer \& Wall, 2000) showing it to be an important aspect of the holiday experience. However, in the UK whilst $72 \%$ of people claim to have taken an interest in local food and drink on their most recent holiday or day out, half claimed to have neither bought nor eaten local food and drink on their current visit (MAFF, 2000). In order to further understand the role local food and 
drink plays in the tourist experience, and why there appears to be disparity between the intention to and actual purchase/consumption of such produce whilst on holiday, this study explores the intention-behaviour gap in this context. Through examining the factors underlying both past and future tourists' motivations to consume local food and drink whilst at a tourist destination, further insight will be offered that will suggest how producers and management may close this intention-behaviour gap.

\section{Theoretical background}

\subsection{Tourism and local food}

The term 'local food' refers to "local food systems or short food chains where the food is produced near the consumer” (Roininen, Arvola, \& Lähteenmäki, 2006, p. 20), and in this study the term 'local food' includes both local food and drink. Local food has been found to be a key driver of tourist destination choice and a major contributor to the tourism experience (Björk \& Kauppinen-Räisänen, 2016). Local food is part of a location’s cultural capital and enhances the travel experience by defining the cultural identity of a particular destination (Bessière, 1998; Cianflone \& Cardile, 2014). Furthermore, local food and food heritage encourages tourism through the "creation or revival of cultural identity” (Vittersø \& Amilien, 2011), and enhances the tourism experience through connecting visitors to a region with local food delivering authentic culinary tourism experiences that symbolise the place and culture of the destination (Chang, Kivela, \& Mak, 2010; Sims, 2009).

Food tourism, defined as "the pursuit and enjoyment of unique and memorable food and drink experiences, both far and near” (World Food Travel Association, 2015), with a particular emphasis on local food products and local food systems is growing in popularity (Pestek \& Nikolic, 2011; Smith \& Xiao, 2008). Indeed, Sims (2009, p. 321) argues that holiday food is becoming more important as it delivers the "sensations of taste, touch, sound 
and smell” which play such an important role in the tourist experience. Björk and Kauppinen-Räisänen (2014) found prospective travellers in Finland use food and eating experiences as evaluative criteria for selecting travel destinations. These eating and food tourism experiences are influenced by the ‘servicescape’ environment (Bitner, 1992; Wakefield \& Blodgett, 2016) i.e., the food itself, where it is served, and how it is served, with eateries playing a key role in how the local food culture is transmitted. Indeed, local restaurants who source and promote local food play an important role in promoting local identity and image, attracting tourists, enhancing visitors’ experiences, and creating a competitive advantage for tourism destinations (Mgonja, Backman, Backman, Moore, \& Hallo, 2017; Presenza \& Del Chiappa, 2013).

In addition to enhancing the tourism experience, local food tourism yields economic, cultural and environmental benefits (Everett \& Aitchison, 2008) and could be argued to be a sustainable model for the economic development of local communities (Sims, 2009). Local food tourism networks increase social and human capital, provide opportunities for local producers and retailers, and allow for a price premium for locally produced food and drink (Dougherty, Brown, \& Green, 2013).

Despite the increased interest in local food and food-related behaviour generally (Mirosa \& Lawson, 2012), research into local food and tourism is limited to date (Björk \& Kauppinen-Räisänen, 2016). Past studies have investigated the area of local food and tourism from different perspectives e.g. cultural, environmental, etc., (e.g., Hjalager \& Johansen, 2013) and influences e.g., attraction, experience, etc., (e.g. Cohen \& Avieli, 2004). Mgonja et al (2017) studied perceptions of international tourists regarding local foods, however this just focused on past knowledge and experiences, and to date no study appears to have investigated whether food consumption-related motivations and behaviour differ pre and post-experience. Given "little is empirically known about tourists' consumption of local 
food” (Frisvoll, Forbord, \& Blekesaune, 2016, p. 77), the current study will undertake an empirical investigation to explore past and future tourists' motivations to consume local food.

\subsection{Intentions and purchase}

A number of studies have explored the purchase behaviour of consumers in relation to local food utilising alternative consumer behaviour theories. For example, Alphabet Theory a theoretical framework for consumer behaviour towards alternative food choices (e.g. Feldmann \& Hamm, 2015) - and concurrent use of attributes, values and personal characteristics/situational variables (Memery, Angell, Megicks, \& Lindgreen, 2015) have been applied in order to understand why consumers buy or do not buy certain items. Indeed, in the context of tourism, local food has been found to be a key area of interest for the majority of people whilst on holiday, with many stating they intend to try/purchase local food whilst away (Björk \& Kauppinen-Räisänen, 2014; MAFF, 2000). However, past research in other consumption contexts indicate there is often a gap between what people intend to do and how they actually behave (e.g. Sheeran, 2002). This is evidenced in the case of food related behaviour e.g. consumption of organic food (Padel \& Foster, 2004) and sustainable food (Vermeir \& Verbeke, 2006). Following this train of evidence, the current study proposes there will be a discrepancy between what visitors intend to do and what they actually do in terms of consuming local food at a destination. To explore if this is the case, and to act as a basis to investigate why this may occur, the current study looks at purchase frequency for past visitors and purchase intention for future visitors to see if there are significant differences. Hence the following hypothesis is proposed:

H1: Purchase frequency of local food products among past visitors is lower than purchase intentions among future visitors 


\subsection{Attitudes and beliefs}

Whilst measuring purchase intentions or past behaviour is vital to help predict future behaviour, it has been recognised that other variables also need to be examined to aid understanding of the underlying factors influencing intention to behave, or behaviour, in a given situation (Kim, Kim, \& Goh, 2011). Past studies indicate such influences are manifested in attitudes and beliefs towards a particular object (i.e., product) (Ajzen \& Fishbein, 1980). To learn and form attitudes, individuals use information sources and opinions to acquire knowledge, with the level of knowledge obtained influencing whether or not a consumer is willing to behave in a given way e.g., purchase an item.

Tourism research provides evidence that tourists vary in their attitudes towards food (Hjalager, 2004) and food experiences hence their interest in, and behaviour around, food and eating differ. Indeed, Björk and Kauppinen-Räisänen (2016) found tourists could be differentiated by their attitudes towards local food (e.g. perceptions of in-trip food-related experiences) which in turn impacted their food related behaviour (e.g., pre-trip information sourcing). However, whilst providing empirical evidence that travellers can be distinguished by their attitudes towards local food and the local food market, their study does not explore whether there are differences between expected and actual experiences and how this might affect attitudes.

Amyx, DeJong, Lin, Chakraborty, and Wiener (1994) argue that the knowledge decisions are based upon can be either subjective or objective, with this knowledge going on to form beliefs. Information sources used to acquire this knowledge can be utilised to form expectations of activities that will be experienced while on holiday (Pestek \& Nikolic, 2011), such as consuming local food. In their study on tourists in Hong Kong, Choe and Kim (2018) found those who perceived high taste/quality value were likely to have a positive attitude toward local food at the destination, and hence form a stronger food destination image of 
Hong Kong. However, as past research has found, if expectations are not met consumers are dissatisfied and hence this will affect their feelings towards an object and beliefs about it (Oliver, 1980). Thus if there is a difference between what tourists expect in terms of local food consumption and what they experience there is likely to be a mismatch between their past and future attitudes/beliefs.

Given this discussion it is considered likely attitudes and beliefs may vary between past and future visitors. Thus the following hypotheses are postulated:

H2: Future visitors hold more favourable attitudes towards local food consumption when visiting a destination than do past visitors

H3: Future visitors have more favourable beliefs about local food consumption when visiting a destination than do past visitors

\subsection{Drivers and barriers to local food purchase}

Local food has been identified as playing an important tourism role, as it affects traveller behaviour and is central to the tourism experience (Björk \& Kauppinen-Räisänen, 2016). Whilst motivational factors are considered important drivers influencing tourist food preference (Mak, Lumbers, Eves, \& Chang, 2012), limited research to date has sought to understand what motivates tourists to consume local food and beverages when visiting a tourism destination (Kim \& Eves, 2012). Early work in the area stemmed from travel motivations (McIntosh, Goeldner, \& Ritchie, 1995) being applied to food-related tourism motivations (Fields, 2002). Kim et al (2009) proposed a model of local food consumption at a holiday destination based around motivational factors, demographic factors and physiological factors. Building on this Kim and Eves (2012) scale development study found five underlying motivations to consume local food and beverages in a tourist destination (cultural experience, interpersonal relation, excitement, sensory appeal, and health concern), whilst Mak et al’s (2012) multidisciplinary review of the literature identified five key 
dimensions of motivation underlying tourist food consumption (symbolic, obligatory, contrast, extension, and pleasure). Whilst these past studies have overviewed relevant literature and employed a range of research methods it is recognised that additional exploration is required through different approaches and research lenses to further identify the range of drivers and barriers influencing this behaviour (Kim \& Eves, 2012) and whether they differ between intended and actual behaviour.

Drawing from the wider food consumption literature an increasing interest in local food can be seen with key drivers of purchasing including better taste, supporting local producers, freshness and better quality (IGD, 2012; Kemp, Insch, Holdsworth, \& Knight, 2010; Megicks, Memery, \& Angell, 2012). Indeed in the context of tourism and local food, key drivers for tourists to purchase local food include supporting the local economy, helping the local environment (MAFF, 2000), as well as being fresh, healthy and wholesome (MAFF, 2000; Mynttinen, Logrén, Särkkä-Tirkkonen, \& Rautiainen, 2015). Furthermore, flavour and taste have been identified as tourist motivations for travel and food consumption and these have been linked to local food consumption (Boniface, 2003; Kim \& Eves, 2012).

The wider food consumption literature also identifies barriers to local food consumption, with these revolving around factors relating to product distractors e.g., limited range, not clearly labelled, and buying inconvenience e.g., time consuming, requires extra effort (Chambers, Lobb, Butler, Harvey, \& Traill, 2007; Megicks et al, 2012). Similarly in a tourism setting barriers to local food consumption tend to arise from difficulty in identifying local foods, lack of information (Birch \& Memery, 2015; Mgonja et al, 2017), lack of awareness, lack of motivation, and lack of opportunity with some people stating it was because they preferred to stick to things they know, and local produce being too expensive (MAFF, 2000). 
Given this discussion, past research indicates similar key drivers and barriers are a consideration for people and the assumption could be made that these will also apply to differing food and drink consumption settings i.e., home, holiday, hence there will be no difference between drivers and barriers to purchase local food whilst visiting a destination. However, Mynttinen et al (2015) found Russian tourists' core motivations to buy local food in Russia were different from their motivations to buy local food whilst holidaying in Finland. Consequently, any perceived trustworthiness of local producers and the traceability aspect of locally produced food, which were found to be significant considerations in Russia, were not mentioned as specific motivators for local food consumption by Russian tourists visiting the South Savo region. This finding may be explained in part by Mak et al (2012) and Sims (2009), who suggested that attitudes towards food and eating are based on a person's environment and circumstances.

The current study looks to build on food consumption literature to allow further identification of key barriers and drivers of local food consumption in the tourism setting. Identifying both drivers and obstacles that may impede the consumption of local food allows for future strategies to be proposed that support local distribution networks and increase food based tourism. Knowledge in the local food consumption area will be extended through exploring perceived drivers and barriers from the viewpoint of both past and future visitors, so allowing identification of any differences between the two groups which may lead to the hypothesised intention-behaviour gap. Hence the following hypotheses are proposed:

H4: Drivers of local food consumption differ across past and future visitors H5: Barriers to local food consumption differ across past and future visitors. 


\section{Methods}

A quantitative approach was followed for data collection to elicit a broader study with a greater number of respondents than a qualitative approach would allow, and to establish the relationships between the intention to purchase and purchase of local food by tourists at a destination through determining whether the empirical evidence supports the hypotheses proposed. An online survey was administered via a professionally managed online market research company to a consumer panel of 546 past/future visitors to South East Queensland (SEQ). Respondents were screened to ensure they were over 18 years of age and in order for responses to come from those most likely to make the decision on what food to consume it was also a requirement that respondents were the main/joint decision maker for household food purchasing decisions. The survey was administered initially to 50 respondents, which acted as a pilot study to check for correctness of data display, understanding and interpretation of questions and the meaningfulness of results. Results of the pilot study indicated no changes were needed to the survey so full data collection followed. Past visitors (those who had visited SEQ in the past 12 months; $\mathrm{n}=370$ ) included 90 visitors from other areas of the state of Queensland (24.3\%) and 280 visitors from interstate (75.7\%); 49.2\% of past visitors in the survey were male and 50.8\% female. Future visitors (those who planned to visit SEQ in the next 12 months; $n=176$ ) included 44 visitors from other areas of the state of Queensland (25.0\%) and 132 visitors from interstate (75.0\%); 36.9\% were male and 63.1\% female. The majority of visitors (31.9\%) were aged 55 years plus, followed by 25-34 years (22.3\%), 35-44 years (20\%), then $45-54$ years (19.6\%) and only 6.2 percent in the $18-24$ year age group.

The survey instrument was informed by the findings of previous studies of local food and beverage (e.g. Megicks et al, 2012; Parker, 2010; SERIO, 2008), and comprised a variety of closed and open-ended questions to capture essential demographic, psychographic and 
behavioural information. Five point frequency and likelihood scales were used to measure purchase frequency by past visitors and purchase intention of future visitors. Seven-point Likert-style questions were used to capture beliefs and attitudes toward local food and the relevance of particular factors (drivers and barriers) when purchasing local food.

\section{Results}

\subsection{Purchasing of local food and drink by visitors (Hypothesis 1)}

Respondents were asked concerning their purchase intentions (future visitors) or actual purchase (past visitors) of local food while visiting SEQ (Table I).

Table I: Purchase of local food and beverage by past and future visitors

\begin{tabular}{lcccccc}
\hline \multicolumn{1}{c}{ Visitor } & Mean & $\mathbf{1}$ & $\mathbf{2}$ & $\mathbf{3}$ & $\mathbf{4}$ & $\mathbf{5}$ \\
Category & $\mathbf{( S D )}$ & $\mathbf{( \% )}$ & $\mathbf{( \% )}$ & $\mathbf{( \% )}$ & $\mathbf{( \% )}$ & $\mathbf{( \% )}$ \\
\hline Past Visitor & 3.3 & 1.1 & 18.1 & 36.5 & 38.1 & 6.2 \\
$(\mathrm{n}=370)$ & $(0.9)$ & & & & & \\
Future Visitor & 3.8 & 0.0 & 8.5 & 27.8 & 43.2 & 20.5 \\
$(\mathrm{n}=176)$ & $(0.9)$ & & & & & \\
\hline
\end{tabular}

Scales: Past Visitors purchases: 5-point Frequency Scale: $1=$ not at all to $5=$ very frequently Future Visitors intentions: 5-point Likelihood Scale: 1 = very unlikely to 5 = completely likely

Descriptive statistics were used to analyse intentions and purchase frequency. While, almost two-thirds (63.8\%) of future visitors to SEQ indicated that they were "likely" or "very likely" to purchase local food and beverage during their visit, less than half (44.3\%) of past visitors reported actually having at least "frequently” done so. Hence, H1 is supported. However, a large proportion of past visitors (36.5\%) selected “neither frequently nor infrequently” and it 
is considered that in line with findings from MAFF (2000), this may be due to them not being aware of whether the food and beverage consumed during the visit was local or not.

\subsection{Attitudes toward local food by visitors (Hypothesis 2)}

Visitors were asked to indicate levels of agreement to statements designed to investigate attitudes toward local food and drink (Table II). 
Table II: Visitors’ attitudes toward local food and drink

\begin{tabular}{|c|c|c|c|c|}
\hline Statement & $\begin{array}{c}\text { Past } \\
\text { visitor } \\
\text { mean (SD) }\end{array}$ & $\begin{array}{c}\text { Future } \\
\text { visitor } \\
\text { mean (SD) }\end{array}$ & t-value & sig \\
\hline $\begin{array}{l}\text { The origin of food and beverage should be clearly identified on menus at } \\
\text { eating out places }\end{array}$ & $5.4(1.3)$ & $5.3(1.2)$ & 0.66 & 0.51 \\
\hline $\begin{array}{l}\text { I am interested in learning about where the local food and beverage I eat } \\
\text { comes from and how it is grown and/or produced }\end{array}$ & $5.1(1.3)$ & $5.0(1.4)$ & 0.74 & 0.46 \\
\hline $\begin{array}{l}\text { If local food and/or beverage was/is promoted at restaurants; that did/will } \\
\text { positively influence me to choose those restaurants }\end{array}$ & $4.9(1.3)$ & $5.3(1.3)$ & -3.39 & $0.01 *$ \\
\hline $\begin{array}{l}\text { Local food and beverage was/should be frequently included on the menus at } \\
\text { eating out places }\end{array}$ & $4.4(1.3)$ & $5.5(1.2)$ & -9.50 & $0.00 *$ \\
\hline $\begin{array}{l}\text { When selecting from a menu at a local restaurant, I specifically looked/will } \\
\text { look for local food and beverage to order }\end{array}$ & $4.4(1.5)$ & $4.7(1.4)$ & -2.58 & $0.01 *$ \\
\hline $\begin{array}{l}\text { When purchasing food and beverage, I specifically looked/will look for local } \\
\text { food and beverage to try }\end{array}$ & $4.5(1.5)$ & $4.8(1.4)$ & -1.97 & $0.05^{*}$ \\
\hline $\begin{array}{l}\text { Local food and beverage was/should be clearly marketed as coming from the } \\
\text { local area }\end{array}$ & $4.2(1.4)$ & $5.5(1.2)$ & -10.93 & $0.00^{*}$ \\
\hline $\begin{array}{l}\text { Local food and beverage was/should be readily available at the places where I } \\
\text { shopped/shop in the local area }\end{array}$ & $4.3(1.3)$ & $5.5(1.1)$ & -10.58 & $0.00 *$ \\
\hline Local food and beverage was/should be branded and easily recognisable & $4.1(1.3)$ & $5.5(1.2)$ & -11.81 & $0.00^{*}$ \\
\hline $\begin{array}{l}\text { Eating and drinking local food and beverage did or could make my visit more } \\
\text { enjoyable }\end{array}$ & $4.9(1.3)$ & $5.0(1.3)$ & -1.07 & 0.29 \\
\hline
\end{tabular}

* Significant difference between means $(\mathrm{p}=<0.05)$. 
Independent t-tests were used to test for mean differences across the two groups. In general, past visitors held less favourable attitudes towards local food and beverage than future visitors $(\mathrm{t}=-6.046, \mathrm{df}=544, \mathrm{p}=0.00)$. Hence, $\mathrm{H} 2$ is supported. However, the majority of both past (74.1\%) and future (73.3\%) visitors agreed that "the origin of food and beverage should be clearly identified on menus at eating out places" and almost two-thirds of past (65.1\%) and future (59.7\%) visitors indicated that they are interested in learning about where the local food and beverage they eat comes from.

Differences in attitudes among past and future visitors were evident with respect to whether they would specifically look for or select local food. Past visitors (61.1\%) were less likely to agree than future visitors (66.5\%) that if local food or beverage was promoted at local restaurants that it did/would positively influence them to choose those restaurants $(\mathrm{t}=$ 3.39, $\mathrm{p}=0.01$ ) indicating a likely gap between intentions and actual behaviour. This may partially be due to local food not being included on menus. Indeed, less than half of past (44.1\%) visitors agreed that local food and beverage was frequently included on menus at eating out places, while $77.8 \%$ of future visitors agreed that local food should be included on menus $(\mathrm{t}=-9.50, \mathrm{p}=0.00)$. Past visitors $(46.5 \%)$ were also less likely to agree than future visitors $(51.7 \%)$ that when selecting from a menu at a restaurant during their visit they did or would "specifically" look for local food and beverage to order $(t=-2.58, \mathrm{p}=0.01)$. Moreover, past visitors (51.4\%) were slightly less likely to agree than future visitors (54.5\%) that when purchasing food and beverage during their visit they did/would specifically look for local food and beverage to try $(\mathrm{t}=-1.97, \mathrm{p}=0.05)$.

In further explaining the intention-purchase gap, more than three-quarters of future visitors (78.4\%) strongly agreed that local food and beverage should be clearly marketed as being local, while only $37.6 \%$ of past visitors agreed that local food had been clearly marketed as local $(\mathrm{t}=-10.93, \mathrm{p}=0.00)$. Likewise, while the majority of future visitors 
(76.7\%) agreed that local food and beverage should be branded and easily recognisable, only about one-third (34.3\%) of past visitors agreed that it had been $(\mathrm{t}=-11.81, \mathrm{p}=0.00)$. Moreover, while the majority of future visitors (76.7\%) agreed that local food and beverage should be readily available, significantly fewer past visitors (41.1\%) agreed that local food had been readily available $(\mathrm{t}=-10.58, \mathrm{p}=0.00)$. Hence, while nearly two thirds of future (59.7\%) and past (60.3\%) visitors agreed that eating and drinking local food and beverage could or did make their visit more enjoyable, it appears that poor marketing and lack of distribution may have led to an intention-behaviour gap with respect to consumption of local food by visitors.

\subsection{Beliefs about local food by visitors (Hypothesis 3)}

Respondents were asked about their beliefs regarding purchasing local food and drink (Table III). 
Table III: Visitors’ beliefs about purchasing local food and beverage

\begin{tabular}{|c|c|c|c|c|}
\hline Statement & $\begin{array}{c}\text { Past } \\
\text { visitor } \\
\text { mean (SD) }\end{array}$ & $\begin{array}{c}\text { Future } \\
\text { visitor } \\
\text { mean (SD) }\end{array}$ & t-value & Sig \\
\hline Overall, I feel that I should try local food and beverage when visiting SEQ & $5.5(1.2)$ & $5.6(1.2)$ & -0.78 & 0.43 \\
\hline Buying local food and beverage when visiting SEQ would be favourable & $5.3(1.1)$ & $5.5(1.1)$ & -1.79 & 0.08 \\
\hline I would feel good if I bought local food and beverage when visiting SEQ & $5.2(1.1)$ & $5.5(1.1)$ & -2.63 & $0.01 *$ \\
\hline Buying local food and beverage when visiting SEQ would be easy & $4.9(1.2)$ & $5.2(1.1)$ & -2.03 & $0.04 *$ \\
\hline
\end{tabular}

* significant difference between means ( $\mathrm{p}=<0.05)$.

Both past (81.4\%) and future (79.0\%) visitors agreed that they should try local food and beverage when visiting South East Queensland, and that to do so would be favourable. However, future visitors (75.6\%) were more likely to agree than past visitors (69.7\%) that they would 'feel good' if they bought local food and beverage when visiting $(\mathrm{t}=-2.63, \mathrm{p}=0.01)$. Moreover, future visitors $(65.3 \%)$ were more likely to agree than past visitors (57.0\%) that people who are important to them would approve of them buying local food and beverage when visiting $(\mathrm{t}=-1.93$, $\mathrm{p}=$ 0.05). Future visitors (67.0\%) were also more likely to agree that buying local food and beverage when visiting would be easy than past visitors $(60.8 \%)(t=-2.03, p=0.04)$. Hence, H3 is also supported, with future visitors holding more favourable beliefs toward local food than past visitors. 


\subsection{Drivers for local food consumption by visitors (Hypothesis 4)}

To explore motivations toward local food consumption, respondents were asked to indicate the extent to which they agreed or disagreed that they are or would be willing to purchase local food and beverage based on a range of specific attributes. To ensure the identification of determinant drivers, only past visitors who had indicated they had eaten local food more than 'infrequently' during their visit $(\mathrm{n}=299)$ and future visitors who indicated that they intended to purchase local food and beverage more than 'infrequently' during their visit $(\mathrm{n}=161)$ were included. Thus, results for future visitors represent purchasing intentions (and thus potentially represent their expectations) while for past visitors they represent actual purchasing behaviour (and thus potentially reflect perceptions of performance).

In general, future visitors were more likely to agree than past visitors that the majority of drivers measured in this study would influence them to purchase local food (Table IV). Hence, H4 is supported with drivers varying across past and future visitors, most likely as a result of an expectations-performance gap (Figure I). 
Table IV: Drivers of visitors' willingness to purchase local food and beverage

\begin{tabular}{|c|c|c|c|c|c|c|c|c|}
\hline \multirow{2}{*}{$\begin{array}{c}\text { I was willing to/will purchase } \\
\text { SEQ local food and beverage } \\
\text { during my visit to the region } \\
\text { because ... }\end{array}$} & \multirow[t]{2}{*}{$\begin{array}{c}\text { Cronbach } \\
\text { Alpha }\end{array}$} & \multirow[t]{2}{*}{$\begin{array}{l}\text { Total } \\
\text { Mean }\end{array}$} & \multicolumn{2}{|c|}{$\begin{array}{c}\text { Past } \\
\text { Visitors } \\
(n=299)\end{array}$} & \multicolumn{2}{|c|}{$\begin{array}{c}\text { Future } \\
\text { Visitors } \\
(\mathbf{n}=\mathbf{1 6 1})\end{array}$} & \multirow[t]{2}{*}{ t-value } & \multirow[t]{2}{*}{ sig } \\
\hline & & & Mean (SD) & \% agree & Mean (SD) & \% agree & & \\
\hline Support Local & 0.87 & 5.5 & & & & & & \\
\hline Support local community & & 5.7 & $5.6(1.1)$ & 81.3 & $5.9(1.1)$ & 83.2 & -2.32 & $0.02 *$ \\
\hline Support local producers & & 5.6 & $5.6(1.2)$ & 82.9 & $5.6(1.1)$ & 80.7 & 0.50 & 0.62 \\
\hline Support local retailers & & 5.3 & $5.5(1.1)$ & 80.9 & $4.9(1.3)$ & 52.2 & 5.36 & $0.00 *$ \\
\hline Intrinsic Qualities & 0.92 & 5.5 & & & & & & \\
\hline Fresh & & 5.7 & $5.7(1.1)$ & 86.6 & $5.6(1.1)$ & 85.1 & 1.08 & 0.24 \\
\hline Tastes good & & 5.6 & $5.6(1.1)$ & 84.6 & $5.8(1.1)$ & 84.5 & -1.76 & 0.08 \\
\hline In season & & 5.5 & $5.5(1.1)$ & 81.6 & $5.6(1.1)$ & 80.7 & -1.50 & 0.13 \\
\hline Healthy & & 5.5 & $5.3(1.1)$ & 76.3 & $5.8(1.0)$ & 84.5 & -4.25 & $0.00 *$ \\
\hline Good appearance & & 5.5 & $5.4(1.1)$ & 77.9 & $5.7(1.0)$ & 82.6 & -2.84 & $0.01^{*}$ \\
\hline Premium Value Product & 0.88 & 5.3 & & & & & & \\
\hline High quality & & 5.5 & $5.4(1.1)$ & 79.6 & $5.8(1.0)$ & 86.3 & -3.86 & $0.00 *$ \\
\hline Best available & & 5.3 & $5.6(1.1)$ & 68.6 & $5.6(1.1)$ & 83.9 & -4.19 & $0.00 *$ \\
\hline Good value for money & & 5.2 & $5.0(1.2)$ & 65.6 & $5.6(1.1)$ & 82.6 & -4.90 & $0.00^{*}$ \\
\hline Reputation & & 5.1 & $5.0(1.2)$ & 63.5 & $5.4(1.1)$ & 74.5 & -3.16 & $0.01^{*}$ \\
\hline
\end{tabular}




\begin{tabular}{|c|c|c|c|c|c|c|c|c|}
\hline Traceability and Provenance & 0.84 & 5.3 & & & & & & \\
\hline I know where it comes from & & 5.4 & $5.2(1.1)$ & 72.6 & $5.6(1.1)$ & 76.4 & -2.99 & $0.01 *$ \\
\hline Traditional to the region & & 5.4 & $5.2(1.2)$ & 68.9 & $5.7(1.1)$ & 82.6 & -4.84 & $0.00 *$ \\
\hline Authentic or original & & 5.2 & $5.2(1.1)$ & 73.9 & $5.2(1.1)$ & 70.8 & -0.19 & 0.85 \\
\hline $\begin{array}{l}\text { Like the connection with local } \\
\text { producers }\end{array}$ & & 5.2 & $5.3(1.2)$ & 73.2 & $5.0(1.3)$ & 59.6 & 2.51 & $0.01 *$ \\
\hline Purity & 0.90 & 5.2 & & & & & & \\
\hline Natural & & 5.4 & $5.2(1.1)$ & 71.6 & $5.8(1.0)$ & 83.2 & -4.89 & $0.00 *$ \\
\hline Free from preservatives & & 5.3 & $4.9(1.2)$ & 55.5 & $6.0(1.1)$ & 88.8 & -9.51 & $0.00 *$ \\
\hline I can trust it & & 5.3 & $5.1(1.2)$ & 68.9 & $5.6(1.1)$ & 81.4 & -4.62 & $0.00 *$ \\
\hline Safe & & 5.2 & $5.1(1.2)$ & 62.2 & $5.6(1.0)$ & 84.5 & -4.52 & $0.00 *$ \\
\hline Free from chemicals & & 4.9 & $4.7(1.2)$ & 62.2 & $5.4(1.2)$ & 84.5 & -5.82 & $0.00 *$ \\
\hline Organic & & 4.9 & $4.5(1.4)$ & 43.1 & $5.7(1.0)$ & 82.6 & -9.54 & $0.00 *$ \\
\hline Sustainability & 0.85 & 5.2 & & & & & & \\
\hline Reduces food miles & & 5.3 & $5.2(1.3)$ & 67.6 & $5.4(1.2)$ & 75.2 & -1.95 & $0.05 *$ \\
\hline Reduces packaging & & 5.2 & $4.8(1.3)$ & 54.5 & $5.9(1.1)$ & 87.0 & -8.95 & $0.00 *$ \\
\hline Sustainable & & 5.1 & $5.1(1.2)$ & 63.9 & $5.2(1.1)$ & 67.7 & -1.10 & 0.27 \\
\hline Environmentally friendly & & 5.0 & $4.9(1.2)$ & 58.2 & $5.3(1.1)$ & 71.4 & -3.88 & $0.00 *$ \\
\hline Hedonic Motivations & 0.83 & 5.1 & & & & & & \\
\hline Makes me feel good & & 5.3 & $5.1(1.2)$ & 66.2 & $5.7(1.1)$ & 80.7 & -5.33 & $0.00 *$ \\
\hline
\end{tabular}




\begin{tabular}{|c|c|c|c|c|c|c|c|c|}
\hline Treat & & 5.3 & $5.1(1.2)$ & 67.2 & $5.6(1.1)$ & 82.0 & -4.49 & $0.00 *$ \\
\hline Interesting and/or novel & & 5.2 & $4.9(1.2)$ & 59.2 & $5.8(1.0)$ & 83.2 & -8.32 & $0.00^{*}$ \\
\hline Marketing and Distribution & 0.80 & 4.9 & & & & & & \\
\hline Widely available & & 5.0 & $4.9(1.2)$ & 59.9 & $5.4(1.2)$ & 72.0 & -4.20 & $0.00 *$ \\
\hline $\begin{array}{l}\text { Branded and easily } \\
\text { recognisable as local }\end{array}$ & & 5.0 & $4.8(1.3)$ & 57.5 & $5.3(1.2)$ & 68.3 & -4.04 & $0.00^{*}$ \\
\hline Promoted nationally & & 4.6 & $4.3(1.2)$ & 34.1 & $5.2(1.2)$ & 67.1 & -7.71 & $0.00^{*}$ \\
\hline Ethical Issues & 0.70 & 4.7 & & & & & & \\
\hline Considers animal welfare & & 4.8 & $4.3(1.2)$ & 31.1 & $5.6(1.1)$ & 80.1 & -10.51 & $0.00^{*}$ \\
\hline Ethical & & 4.7 & $4.7(1.3)$ & 48.8 & $4.8(1.2)$ & 50.3 & -0.34 & 0.74 \\
\hline Feel guilty if I do not & & 4.2 & $3.7(1.5)$ & 26.1 & $5.1(1.1)$ & 64.6 & -10.14 & $0.00^{*}$ \\
\hline
\end{tabular}


Figure I: Past and future visitors drivers to purchase local food and beverage

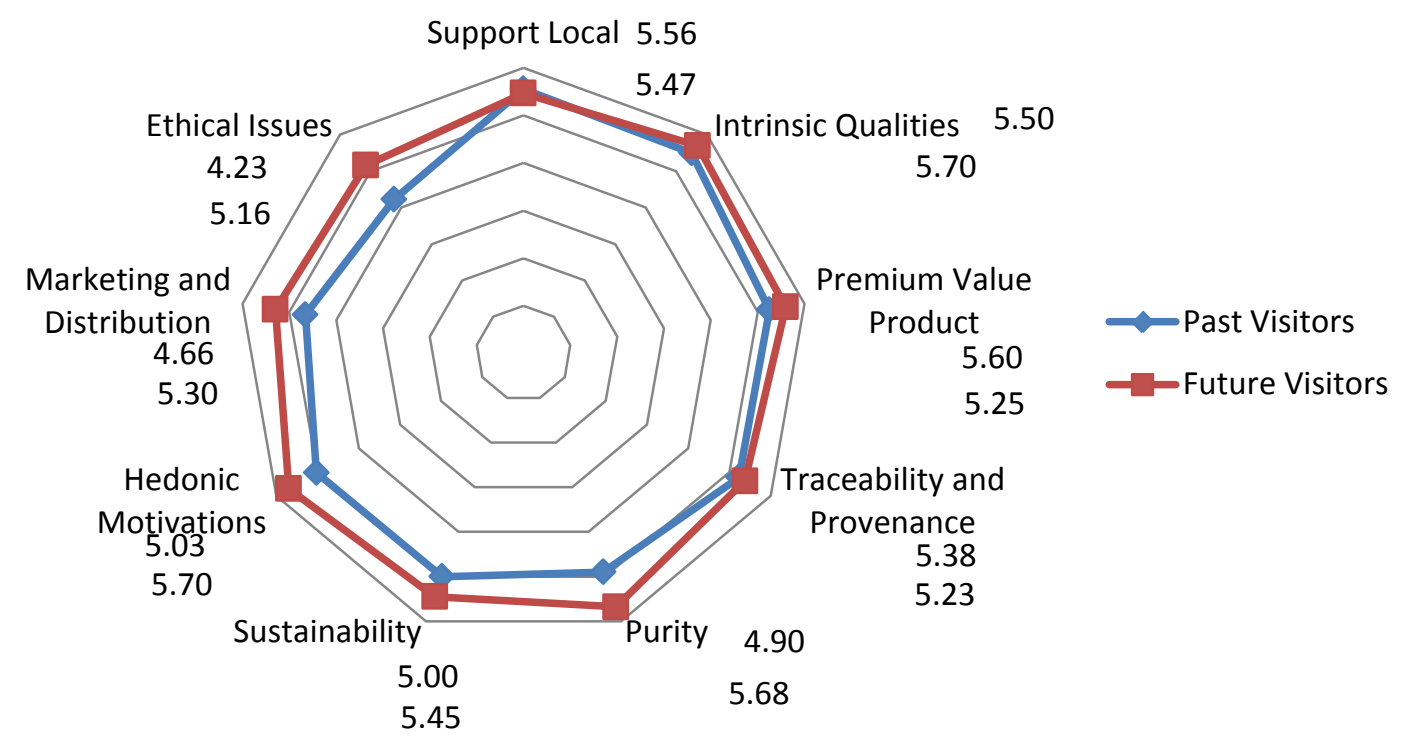

\subsection{Barriers to local food consumption by visitors (Hypothesis 5)}

To identify determinant barriers, only past visitors who indicated that they had purchased local foods infrequently while visiting SEQ $(n=71)$ and future visitors $(n=15)$ who indicated it was unlikely they would purchase local foods while visiting SEQ, were asked reasons for non-purchasing. Hence, the small number of future visitors reporting on barriers $(n=15)$ means only inferences can be made about future visitors’ perceptions of barriers and any differences across visitor groups.

Overall, past visitors were more likely to agree than future visitors that many of the barriers measured in this study would prevent them from purchasing local food (Table V). Hence, H5 is supported with barriers varying across past and future visitors, most likely as a result of an expectations-performance gap (Figure II). 
Table V: Barriers to visitors’ willingness to purchase local food and beverage

\begin{tabular}{|c|c|c|c|c|c|c|c|c|}
\hline $\begin{array}{l}\text { I was NOT willing to/will not purchase } \\
\text { local food and beverage during my visit to }\end{array}$ & $\begin{array}{l}\text { Cronbach } \\
\text { Alpha }\end{array}$ & $\begin{array}{l}\text { Total } \\
\text { Mean }\end{array}$ & $\begin{array}{l}\text { Past } \\
\text { Visitors } \\
(n=71)\end{array}$ & & $\begin{array}{l}\text { Future } \\
\text { Visitors } \\
(n=15)\end{array}$ & & t-value & sig \\
\hline & & & Mean (SD) & \% agree & Mean (SD) & $\%$ agree & & \\
\hline Lack of Marketing & 0.71 & 4.5 & & & & & & \\
\hline $\begin{array}{l}\text { Information on where to find it is not } \\
\text { available }\end{array}$ & & 4.9 & $4.9(1.1)$ & 63.4 & $5.1(0.9)$ & 73.3 & -0.64 & 0.52 \\
\hline Not well promoted & & 4.7 & $4.8(1.2)$ & 60.6 & $4.5(0.8)$ & 60.0 & 0.77 & 0.45 \\
\hline Not well labelled & & 4.6 & $4.5(1.1)$ & 52.1 & $4.9(1.0)$ & 60.0 & -1.45 & 0.15 \\
\hline Not clearly branded as local & & 4.6 & $4.6(1.2)$ & 47.9 & $4.5(1.1)$ & 46.7 & 0.13 & 0.90 \\
\hline Not well packaged & & 3.9 & $3.8(1.0)$ & 19.7 & $4.5(1.1)$ & 53.3 & -2.43 & $0.02 *$ \\
\hline Lack of Distribution & 0.79 & 4.5 & & & & & & \\
\hline Not readily available & & 4.6 & $4.5(1.2)$ & 47.9 & $5.1(1.0)$ & 66.7 & -2.08 & $0.04 *$ \\
\hline Range of products is limited & & 4.4 & $4.3(1.0)$ & 33.8 & $4.9(0.9)$ & 60.0 & -2.14 & $0.04 *$ \\
\hline Inconvenience & 0.83 & 4.4 & & & & & & \\
\hline Have to travel further to do so & & 4.4 & $4.2(1.2)$ & 32.4 & $5.2(0.9)$ & 80.0 & -3.01 & $0.01^{*}$ \\
\hline Requires extra effort & & 4.4 & $4.3(1.1)$ & 42.3 & $5.0(0.7)$ & 80.0 & -2.41 & $0.02 *$ \\
\hline
\end{tabular}




\begin{tabular}{|c|c|c|c|c|c|c|c|c|}
\hline To do so is time consuming & & 4.3 & $4.2(1.1)$ & 35.2 & $4.9(0.9)$ & 60.0 & -2.14 & $0.04^{*}$ \\
\hline It is inconvenient & & 4.3 & $4.1(1.1)$ & 35.2 & $5.3(1.0)$ & 73.3 & -3.93 & $0.00 *$ \\
\hline Price and Quality Issues & 0.66 & 4.1 & & & & & & \\
\hline Expensive & & 4.3 & $4.1(1.0)$ & 28.2 & $5.1(1.2)$ & 66.7 & -3.06 & $0.01 *$ \\
\hline $\begin{array}{l}\text { Food and beverage is sometimes better } \\
\text { elsewhere }\end{array}$ & & 4.2 & $4.1(1.0)$ & 28.2 & $4.6(0.6)$ & 53.3 & -1.83 & 0.07 \\
\hline Not good quality & & 3.7 & $3.4(0.9)$ & 4.2 & $5.0(1.4)$ & 60.0 & -5.33 & $0.00 *$ \\
\hline Lack of Trust & 0.74 & 4.0 & & & & & & \\
\hline $\begin{array}{l}\text { Cannot trust that all of the ingredients are } \\
\text { local }\end{array}$ & & 4.0 & $3.9(1.1)$ & 19.7 & $4.4(1.1)$ & 40.0 & -1.69 & 0.09 \\
\hline Cannot trust it is actually local & & 4.0 & $3.8(1.0)$ & 19.7 & $4.7(1.3)$ & 53.3 & -2.96 & $0.01 *$ \\
\hline
\end{tabular}


Figure II: Past and future visitors barriers to purchase local food and beverage

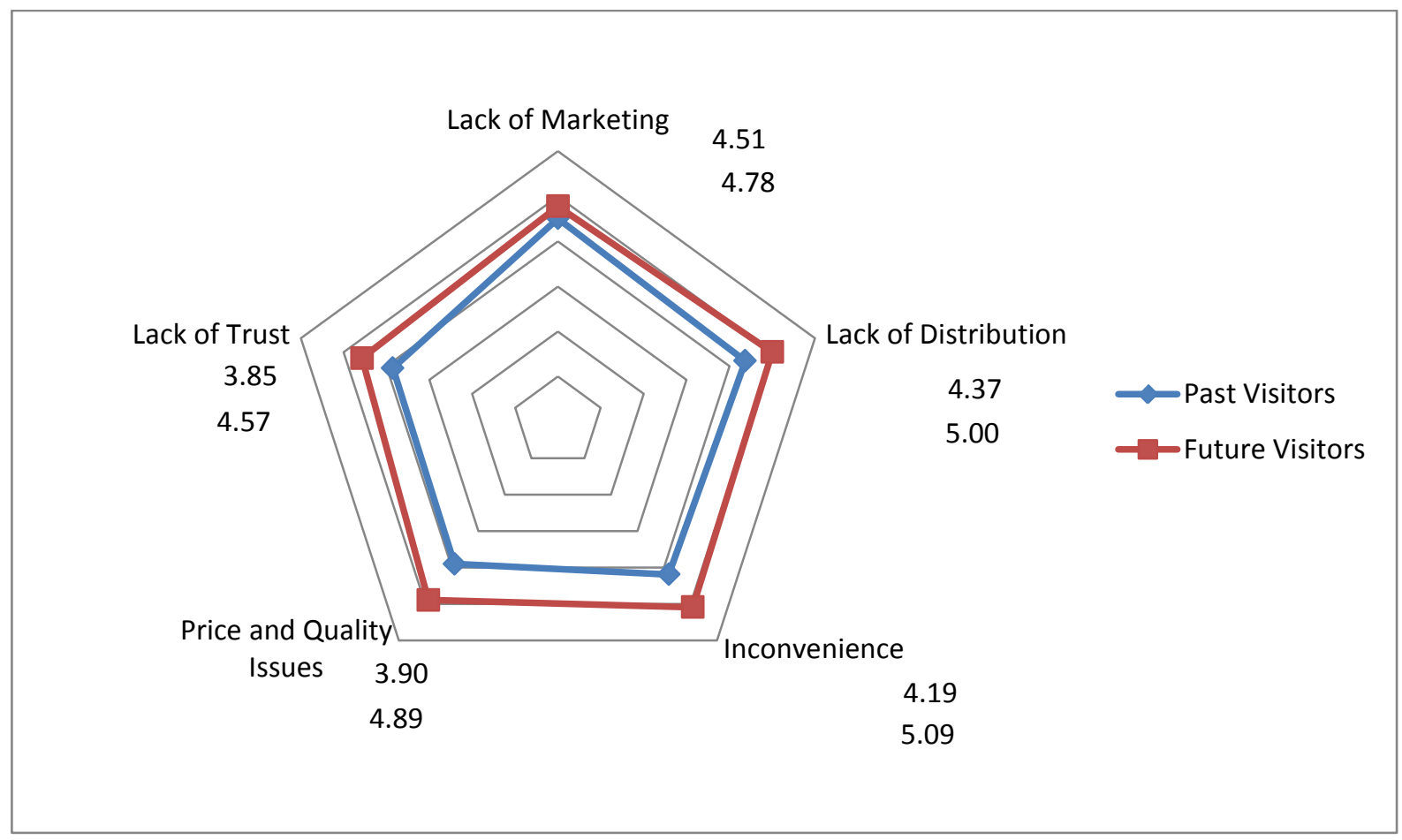

\section{Discussion}

\subsection{Theoretical implications}

In line with previous studies of local food tourism, local food was found to be a major contributor to the tourism experience (Björk \& Kauppinen-Räisänen, 2016) with future visitors reported high levels of intention to purchase local food and beverage during their visit to South East Queensland (MAFF, 2000). In support of H1, the lesser frequency of actual purchase reported by past visitors indicates that visitors do not always act on these good intentions (MAFF, 2000). Outcomes from testing of Hypotheses 2, 3 and 5 support findings in both the wider food consumption literature (Chambers et al, 2007; Megicks et al, 2012) and food tourism literature (Birch \& Memery, 2015; Mgonja et al, 2017), revealing that reasons for non-purchase among visitors relate to less favourable attitudes and beliefs, and higher perceived barriers to consumption including poor marketing and distribution, perceived 
inconvenience, price and quality issues and lack of trust that the product and its ingredients are actually local.

Past and future visitors shared similar and positive attitudes in terms of being interested in where the local food and beverage they eat comes from, agreeing that the origin of food should be included on menus, and that if local food or beverage was promoted at local restaurants it would positively influence them to choose those restaurants. Whilst Sims (2009) found over $60 \%$ of her interviewees stated they had deliberately chosen to consume food or drink they considered "local" while on holiday, in the current study less than half of past visitors agreed they had specifically looked for local food and beverage to order or try during their visit. While more than three-quarters of future visitors agreed local food and beverage should be frequently included on menus at eating out places, less than half of the past visitors agreed this had been the case. Over three quarters of future visitors agreed that local food and beverage should be clearly marketed as coming from the region and branded and easily recognisable; however, less than half of the past visitors agreed that local food had been clearly marketed and only onethird agreed that it had been branded or was easily recognisable. Likewise, while over threequarters of future visitors agreed that local food and beverage should be readily available where they shop in the region, less than half of past visitors agreed that it had been. This outcome supports Mgonja et al (2017) who discovered there was ‘provisioning inadequacy’ of local foods or information about local foods in hotels tourists frequented.

These findings support a clear link between favourable attitudes and purchase intentions (Choe \& Kim, 2018); however the link between favourable attitudes and actual purchase is weaker, a result evidenced in previous food related literature (e.g. Padel \& Foster, 2004; Vermeir \& Verbeke, 2006). Results indicate barriers to consumption including poor marketing and lack of distribution may have led to an intention-behaviour gap with respect to consumption of local food by visitors. 
While both past and future visitors held similar beliefs about local food in terms of agreeing they should try local food and beverage when visiting, and that to do so would be favourable, past visitors held less favourable beliefs regarding feeling good if they bought local food, that people who are important to them would approve of them buying local food or that buying local food and beverage when visiting would be easy. Once again this indicates that the experience of actually purchasing local food may not meet past visitors expectations in terms of hedonistic value or convenience.

In line with previous studies (IGD, 2012; Kemp et al, 2010; Mynttinen et al, 2015), key drivers for visitors to purchase local food include supporting local producers, retailers and the local community, the intrinsic qualities of the product itself, the premium value delivered by local produce and the traceability and provenance of the food/drink (Megicks et al, 2012; Sims, 2009). Testing of $\mathrm{H} 4$ revealed some differences with respect to drivers of local food consumption across past and future visitors. While issues related to sustainability such as reducing food miles and packaging and being environmentally friendly appear to influence the purchase intentions of future visitors, past visitors appear to have been less driven by such concerns to purchase local food. Moreover, future visitors, in particular, appear to be influenced by hedonistic motivations such as it makes them feel good, it is a treat and it is interesting and novel. While future visitors indicated that wide availability of local food, local food being branded and easily recognisable as local and promoted nationally would influence them to buy local food, past visitors were less likely to agree that these marketing and distribution factors had driven their actual purchasing behaviour (Birch \& Memery, 2015).

In support of previous studies about obstacles to local food consumption (Chambers et al, 2007) a key barrier to purchasing local food is inadequate marketing including lack of information on where to find local food, local food not being well promoted or clearly branded as local and local food not being clearly labelled or well packaged. Moreover, inadequate distribution of local food in terms of not being readily available and a limited range of products 
lead to reduced purchase of local food by visitors. Poor perceptions around price with local food being too expensive and poor quality levels also present a barrier to visitors purchasing local food, as does the lack of trust that the product and its ingredients are actually local.

\subsection{Service provider and managerial implications}

Given tourists’ favourable attitudes toward purchasing local food, further strengthening these will reduce the intention-behaviour gap. The origin of food and beverage should be clearly identified on menus at eating out places and provenance information ('stories') should be provided as people are interested in learning about where the local food and beverage they consume comes from. Identifying the origin of food on menus, and including and promoting local food and beverage at local restaurants will encourage visitors to specifically look for local food and beverage to order. In addition, influencing positive beliefs toward local food will also address the intention-behaviour gap of visitors by positively influencing perceptions that purchasing local food is favourable, makes people feel good and is easy. Indeed financial benefits may be forthcoming for service providers and management that do this, as Everett and Aitchison (2008) found increasing appreciation of local food by tourists resulted in a significant proportion being willing to pay more for locally identifiable products that support the local heritage and are regionally distinctive.

Another strategy for reducing the intention-behaviour gap for local food purchasing is highlighting the benefit of providing support for local producers, retailers and the community as well as the regional economy. Conversion of intentions to actual purchase will also rely on local food producers and food processors delivering high quality, fresh, great-tasting, seasonal products that both look good and provide value for money. This is particularly important for increasing the likelihood of consumption among future visitors, who undoubtedly will be looking for such products in local restaurants and retail outlets. Past visitors, in particular, indicated they like to know where their food comes from and the connection with local producers, hence providing opportunities for consumers to interact with local producers and 
gain important provenance information (where and how the food is produced) will facilitate the materialisation of purchase intentions.

Many consumers are seeking authentic and original products that are traditional to the region, while others value interesting and novel products, and products that are nostalgic or remind them of the past. Local food and beverage producers should consider how they can enhance the hedonic and experiential benefits consumers are seeking when purchasing local food and beverage, and in particular future visitors, including delivering satisfying and fun shopping experiences, and allowing consumers to enjoy a treat.

Findings reveal that past visitors consider there to be some lack of variety and that local food and beverage is not readily available, hence what visitors might anticipate to be the case prior to their visit may not manifest itself in the actual and hence further compound the intention-behaviour gap. Increasing opportunities for visitors to purchase local products through more strategic and intensive distribution will reduce the intention-behaviour gap. A lack of clear marketing, branding and availability of local food and beverage is evident, and this contributes to the finding that just over half of visitors are specifically looking for local food and beverage to try. Developing stronger marketing and branding strategies for local food and beverage and making local food and beverage more readily available will increase awareness and likelihood of consumption. Furthermore building a 'brand' or 'image' around an area’s local food and drink offering can improve the economic and environmental sustainability of a region through attracting more visitors and investment (Sims, 2009) and provide potential for developing food specialties as food souvenirs (Lin \& Mao, 2015). As Everett and Aitchison (2008) found many foodstuffs (meat, bread, cheese, etc.) are not season dependent, so allowing local businesses and service providers to offer fresh, quality produce and experiences over a longer period/all year round. Better communication of this fact should be used to encourage tourists to visit over a longer period of time (not just peak season) and 
hence provide more robust and sustainable markets in which to sell local produce, so benefiting the local economy and community.

\subsection{Limitations and future research}

This study focused on one region of Australia and Australian residents, and thus could be replicated for international visitors and in other regions and countries where opportunities for local food tourism are evident. This study highlights the influence of attitudes, beliefs, drivers and barriers on local food consumption, however, other factors influencing the gap between purchase intentions and actual purchase of local food including ethical identity, local identity, food involvement and food related lifestyle among others could also be investigated. The small number of future visitors indicating that they were unlikely to purchase local food may have influenced the findings related to perceived barriers relevant to future visitors, and thus findings related to gaps between intention and purchasing of local food related to barriers should be considered as inferential. We acknowledge that the findings based on asking past visitors to reflect on what occurred in the past 12 months may be impacted by inability to accurately recall consumption behaviour. The lack of extant literature comparing past and future visitors with respect to attitudes towards, beliefs about, and perceptions of drivers and barriers to local food consumption has made it difficult to compare the results of this study with previous studies, and thus highlights the need for future studies of local food tourism to consider the different perspectives of future and past visitors in order to understand potential reasons for gaps between purchase intentions and actual consumption (Frisvoll et al, 2016). Furthermore, to strengthen findings further, future studies would ideally be longitudinal in nature, so enabling prospective tourists to be tracked over time from pre-visiting a destination to post-visit and hence allow the same individual's purchase intentions and actual purchase behaviour to be measured. 


\section{References}

Ab Karim, S., \& Chi, C. G-Q. (2010). Culinary Tourism as a Destination Attraction: An Empirical Examination of Destinations' Food Image. Journal of Hospitality Marketing \& Management, 19(6), 531-555.

Ajzen, I., \& Fishbein, M. (1980). Understanding attitudes and predicting social behaviour. Englewood Cliffs, NJ: Prentice Hall.

Amyx, D. A., DeJong, P. F., Lin, X., Chakraborty, G., \& Wiener, J. L. (1994).Influencers of purchase intentions for ecologically safe products: an exploratory study. In Marketing theory and applications, proceedings of the 1994 AMA Winter Educators Conference (pp. 341-347).

Bessière, J. (1998). Local development and heritage: traditional food and cuisine as tourist attractions in rural areas. Sociologia Ruralis, 38(1), 21-34.

Birch, D., \& Memery, J. (2015, June). Exploring the intention-behaviour gap for tourists consumption of local food: A case of South East Queensland, Australia. Paper presented at the International Food Marketing Research Symposium, Chania, Crete.

Bitner, M. J. (1992). Servicescapes: The impact of physical surroundings on customers and employees. Journal of Marketing, 56(April), 57-71.

Björk, P., \& Kauppinen-Räisänen, H. (2014). Culinary-gastronomic tourism - a search for local food experiences. Nutrition \& Food Science, 44(4), 294-309.

Björk, P., \& Kauppinen-Räisänen, H. (2016). Local food: a source for destination attraction. International Journal of Contemporary Hospitality Management, 28(1), 177-194.

Boniface, P. (2003). Tasting tourism: Travelling for food and drink. Aldershot, Burlington, Vt: Ashgate.

Chambers, S., Lobb, A., Butler, L., Harvey, K., \& Traill, B. (2007. Local, national and imported foods: a qualitative study. Appetite, 49(1), 208-213. 
Chang, R. C. Y., Kivela, J., \& Mak, A. H. N. (2010). Food Preferences of Chinese Tourists. Annals of Tourism Research, 37(4), 989-1011.

Choe, J. Y., \& Kim, S. (2018). Effects of tourists’ local food consumption value on attitude, food destination image, and behavioral intention. International Journal of Hospitality Management, 71(April), 1-10.

Cianflone, E., \& Cardile, G. (2014). Local agricultural products in tourism: AJ Strutt's account of Sicilian prickly pears. Geojournal of Tourism and Geosites, 13(1), 10-16.

Cohen, E., \& Avieli, N. (2004). Food in tourism attraction and impediment. Annals of Tourism Research, 31(4), 755-778.

Correia, A., Moital, M., Da Costa, C. F., \& Peres, R. (2008). The determinants of gastronomic tourists’ satisfaction. Journal of Food Service, 19(3), 164-176.

Dougherty, M. L., Brown, L. F., \& Green, G. P. (2013). The social architecture of local food tourism: Challenges and opportunities for community economic development. Journal of Rural Social Sciences, 28(2), 1-27.

Everett, S., \& Aitchison, C. (2008). The Role of Food Tourism in Sustaining Regional Identity: A Case Study of Cornwall, South West England. Journal of Sustainable Tourism, 16(2), $150-167$.

Feldmann, C., \& Hamm, U. (2015). Consumers’ perceptions and preferences for local food: A review. Food Quality and Preference, 40(March), 152-164.

Fields, K. (2002). Demand for the gastronomy tourism product: motivational factors. In A. Hjalager, \& G. Richard (Eds.), Tourism and Gastronomy (pp.37-50). London, UK: Routledge.

Frisvoll, S., Forbord, M., \& Blekesaune, A. (2016). An empirical investigation of tourists’ consumption of local food in rural tourism. Scandinavian Journal of Hospitality and Tourism, 16(1), 76-93.

Henderson, J. C. (2009). Food Tourism Reviewed. British Food Journal, 111(4), 317-326. 
Hjalager, A. M. (2004). What do tourists eat and why? Towards a sociology of gastronomy in tourism. Tourism, 52(2), 195-201.

Hjalager, A. M., \& Johansen, P. H. (2013). Food tourism in protected areas-sustainability for producers, the environment and tourism. Journal of Sustainable Tourism, 21(3), 417-433.

Horng, J-S., Liu, C-H., Chou, H-Y., \& Tsai, C-Y. (2012). Understanding the Impact of Culinary Brand Equity and Destination Familiarity on Travel Intentions. Tourism Management, 33(4), 815-824.

IGD (Institute of Grocery Distribution). (2012). Local Food. Retrieved from http://www.igd.com/Research/Shopper-Insight/ethics-and-health/4132/Local-Food/.

Kemp. K., Insch, A., Holdsworth, D. K., \& Knight, J. G. (2010). Food miles: Do UK consumers actually care? Food Policy, 35(6), 504-513.

Kim, Y., \& Eves, A. (2012). Construction and validation of a scale to measure tourist motivation to consume local food. Tourism Management, 33(6), 1458-1467.

Kim, Y. G., Eves, A., \& Scarles, C. (2009). Building a model of local food consumption on trips and holidays: A grounded theory approach. International Journal of Hospitality Management, 28(3), 423-431.

Kim, Y. H., Kim, M., \& Goh, B. K. (2011). An examination of food tourist's behavior: Using the modified theory of reasoned action. Tourism Management, 32(5), 1159-1165.

Kivela, J., \& Crotts, J. (2006). Tourism and gastronomy: gastronomy’s influence on how tourists experience a destination. Journal of Hospitality and Tourism Research, 30(3), 354377.

Lee, K-H., Scott, N., \& Packer, J. (2014). Where Does Food Fit in Tourism? Tourism Recreation Research, 39(2), 269-274.

Lin. L. \& Mao, P-C. (2015). Food for memories and culture - A content analysis study of food specialties and souvenirs. Journal of Hospitality and Tourism Management, 22(March), 1929. 
MAFF, (2000). Tourists Attitudes Towards Regional and Local Foods. London, UK; Ministry of Agriculture Fisheries and Food and the Countryside Agency.

Mak, A. H. N., Lumbers, M., Eves, A., \& Chang, R. C. Y. (2012). Factors influencing tourist food consumption. International Journal of Hospitality Management, 31, 928-936.

Mak, A. H. N., Lumbers, M., Eves, A., \& Chang, R. C. Y. (2017). The effects of food-related personality traits on tourist food consumption motivations. Asia Pacific Journal of Tourism Research, 22(1), 1-20.

McIntosh, R., Goeldner, C., \& Ritchie, J. (1995). Tourism principles, practices, philosophies (7th ed.). New York, N.Y: Wiley.

McKercher, B., Okumus, F., \& Okumus, B. (2008). Food tourism as a viable market segment: it is all how you cook the numbers! Journal of Travel and Tourism Marketing, 25(2), 137148.

Megicks, P., Memery, J., \& Angell, R. (2012). Understanding local food shopping: unpacking the ethical dimension. Journal of Marketing Management, 28(3/4), 264-289.

Memery, J., Angell, R., Megicks, P., \& Lindgreen, A. (2015). Unpicking motives to purchase locally-produced food: analysis of direct and moderation effects. European Journal of Marketing, 49(7/8), 1207-1233.

Mgonja, J. T., Backman, K. F., Backman, S. J., Moore, D. D., \& Hallo, J. C. (2017). A structural model to assess international visitors' perceptions about local foods in Tanzania. Journal of Sustainable Tourism, 25(6), 796-816.

Mirosa, M., \& Lawson, R. (2012). Revealing the lifestyles of local food consumers. British Food Journal, 114(6), 816-825.

Mynttinen, S., Logrén, J., Särkkä-Tirkkonen, S., \& Rautiainen, T. (2015). Perceptions of food and its locality among Russian tourists in the South Savo region of Finland. Tourism Management, 48, 455-466. 
Oliver R. L. (1980). A Cognitive Model of the Antecedents and Consequences of Satisfaction Decisions. Journal of Marketing Research, 17(4), 460-69.

Padel, S., \& Foster, C. (2005). Exploring the gap between attitudes and behaviour: Understanding why consumers buy or do not buy organic food. British Food Journal, 107(8), 606-625.

Parker, J. (2010). Consumer awareness and behaviour survey relating to production, distribution and consumption of local foods, Coffs Harbour, NSW, AU; Jetty Research Ltd.

Pestek, A., \& Nikolic, A. (2011). Role of traditional food in tourist destination image building: example of the city of Mostar. UTMS Journal of Economics, 2(1), 89-100.

Presenza, A., \& Del Chiappa, G. (2013). Entrepreneurial strategies in leveraging food as a tourist resource: a cross-regional analysis in Italy. Journal of Heritage Tourism, 8(2/3), 182192.

Roininen, K., Arvola, A., \& Lähteenmäki, L. (2006). Exploring consumers’ perceptions of local food with two different qualitative techniques: Laddering and word association. Food quality and preference, 17(1), 20-30.

Sengel, T., Karagoz, A., Cetin, G., Dincer, F. I., Ertugral, S. M., \& Balık, M. (2015). Tourists' Approach to Local Food. Procedia-Social and Behavioral Sciences, 195, 429-437.

Seo, S., Yun, N., \& Kim, O. Y. (2014). Destination food image and intention to eat destination foods: a view from Korea. Current Issues in Tourism, 1-22.

SERIO, (2008). Understanding of consumer attitudes and actual purchasing behaviour with reference to local and regional foods. Retrieved from http://www.serio.ac.uk/resources/files/Understanding\%20of\%20Consumer\%20Attitudes\%2 0and\%20Actual\%20Purchasing\%20Behaviour.pdf.

Sheeran, P. (2002). Intention-behavior relations: A conceptual and empirical review. European Review of Social Psychology, 12(1), 1-36. 
Sims, R. (2009). Food, place and authenticity: local food and the sustainable tourism experience. Journal of Sustainable Tourism, 17(3), 321-336.

Smith, S., \& Xiao, H. (2008). Culinary Tourism Supply Chains: A Preliminary Examination. Journal of Travel Research, 46(3), 289-99.

Telfer, D. J., \& Wall, G. (2000). Strengthening backward economic linkages: Local food purchasing by three Indonesian hotels. Tourism Geographies, 2(4), 421-447.

Vermeir, I., \& Verbeke, W. (2006). Sustainable food consumption: Exploring the consumer “attitude-behavioral intention” gap. Journal of Agricultural and Environmental Ethics, 19(2), 169-194.

Vittersø, G., \& Amilien, V. (2011). From tourist product to ordinary food? The role of rural tourism in development of local food and food heritage in Norway. Anthropology of Food, 15(8), unpaginated. Retrieved from http://aof.revues.org/6833.

Wakefield, K. L., \& Blodgett, J. (2016). Retrospective: the importance of servicescapes in leisure service settings. Journal of Services Marketing, 30(7), 686-691.

World Food Travel Association. (2015). Defining Food Tourism. Retrieved from http://worldfoodtravel.org/what-is-food-tourism/ 